ISSN 0258-7122 (Print), 2408-8293 (Online)

Bangladesh J. Agril. Res. 44(2): 239-251, June 2019

\title{
CHARACTERIZATION AND DIVERSITY OF BLACKGRAM GERMPLASM
}

\author{
M. T. ISLAM ${ }^{1}$, S. RAHMAN ${ }^{2}$, M. A. MALEK ${ }^{3}$ \\ I. AHMED ${ }^{4}$ AND T. JAHAN ${ }^{5}$
}

\begin{abstract}
The experiment was conducted with 61germplasm of blackgram (Vigna mungo (L.) Hepper) in a Randomized Complete Block Design with 3 replications at the Plant Genetic Resources Centre of BARI Gazipur during March to June 2012 to know the diversity of germplasm. Two to four classes were observed among the 14 qualitative characters. Green and purple colours were found in epicotyl, petiole and stem. Light green to dark green was found in case of leaf and immature pods. Erect, semi-erect and spreading growth habit along with indeterminate and determinate growth pattern were observed. Ovate, ovatelanceolate and rhombic terminal leaflet shape were found. Erect to sub-erect pod attachment to peduncle with glabrous to densely pubescent pods were found. The accessions showed black and brown mature pods having hook and knob types of pod beak shape. Black, brown, grayed-orange and yellow-green seed colours were observed among the blackgram accessions. Low to high phenotypic diversity index $(0.12$ to 0.91$)$ were found among the qualitative characters. All the accessions exhibited purple hypocotyl, none twining tendency, glabrous leaf pubescence, abundant leafiness, very light green calyx, yellow flower, drum-shaped seeds, absent seed luster and non-concave seed hilum. Number of seeds per pod ranged from 5 to 7 and hundred seed weight ranged from 1.83 to $4.49 \mathrm{~g}$. The highest PCV was observed in branch length $(32.65 \%)$ and the lowest PCV was found in pod length $(6.99 \%)$. The accessions were grouped into five clusters. Accessions collected from the same districts felt into different clusters. The inter and intra cluster distances ranged from 3.37 to 11.38 and 0.30 to 1.17 , respectively. The maximum number of pods per plant, pod length and 100-seed weight was found in cluster IV. Accessions BD-6853, BD-6857, BD-6863, BD-6865 and BD-6866 were identified as potential germplasm for varietal improvement programme.
\end{abstract}

Keyword: Vigna mungo, characterization, inter cluster and diversity index.

\section{Introduction}

Blackgram (Vigna mungo (L.) Hepper) is an important pulse crop in Bangladesh. It contains $21-23 \%$ protein. It is grown on approximately 41,635 ha of land across the country, yielding an average of 0.94 ton per hectare for a total yield of about 39187 ton (BBS, 2018). The blackgram produced in Bangladesh and India is almost entirely used for domestic purpose as food. In Thailand the production

\footnotetext{
${ }^{1-5}$ Plant Genetic Resources Centre, Bangladesh Agricultural Research Institute (BARI), Joydebpur, Gazipur-1701, Bangladesh
} 
ranges between 80000 and $99000 \mathrm{t}$ annually, and is mainly exported to Japan for bean sprouts. In Japan blackgram is preferred to green gram (Vigna radiata) for bean sprouts for its longer shelf life. Blackgram is a promising legume crop of South and South East Asia (Gupta et al. 2001). BARI has released four varieties of blackgram like BARI Mash-1 (Panth), BARI Mash-2 (Saroth), BARI Mash-3 (Hemanta) and BARI Mash-4 for growing during Kharif-1 (March) and Kharif$1 I$ (August). Seventy seven accessions of blackgram are being maintained in gene bank of PGRC, BARI. Prior to exploitation of genetic resources they should be systematically evaluated for characterization and genetic diversity. Characterization consists of recording those characters which are highly heritable, can easily be seen by nacked eye and are expressed in all environments (IBPGR, 1985). Characterization should provide a standardized record of readily assessable plant characters, which go a long way to identify an accession (Frankel, 1986). It is the description of plant germplasm. It determines the expression of highly heritable characters ranging from morphological, physiological or agronomical features to seed proteins and oil or molecular markers (FAO, 2014). Useful descriptors can also be found in the publications of the International Union for the Protection of New Varieties of Plants (UPOV) and of the USDA's National Plant Germplasm System (NPGS). Use of internationally agreed standards for characterization data increases the usefulness of the published data. Many authors work on characterization, variability and diversity of blackgram germplasm but none or a few studies used the blackgram germplasm from Bangladesh (Gupta et al., 2001, Mishra, 1983, Yashoda et al., 2016; Sinha et al., 2018; Patidar et al., 2018; Jeevitha et al., 2018). Genetic diversity is a basic tool to determine the diverse genotype and it represents the diverse forms. Considering to the above mentioned background, the present study on blackgram has been conducted with the following objectives.

1. To characterize and study the diversity of blackgram germplasm

2. To identify the potential germplasm

\section{Materials and Methods}

The experiment was conducted at the PGRC of BARI, Joydebpur, Gazipur, during February to June 2012. Sixty-one germplasm including four released varieties, BARI Mash-1 (BD-6871), BARI Mash-2 (BD-6872), BARI Mash-3 (BD-6873) and BINA Mash-1 were used in this study. The accessions were collected from different districts of Bangladesh like Chapai Nawabganj (9),Tangail (6), Cumilla (1), Jamalpur (1), Jessore (1), Moulvibazar (1), Mymensingh (1), Rangpur (1), Sherpur (1), India (3) and unknown (32) by the Pulse Research Centre, Ishurdi Pabna during 1981 to 1989 and were conserved at PGRC. The soil of the experimental field was silty clay in texture, having a $\mathrm{pH}$ of 6.5. The soil contained very low organic matter $(0.8 \%)$, low phosphorus (13 $\mathrm{mg} / \mathrm{kg})$, and medium potash (0.19 meq $100 \mathrm{~g}^{-1}$, Anwar et al., 2000).The seeds per accession were planted in two rows of $3 \mathrm{~m}$ long plot on 4 March 2012. Row to 
row distance was $40 \mathrm{~cm}$. Watering was done after sowing for proper germination of seeds and continued upto seedling establishment. The experiment was conducted in Randomized Completely Block Design with three replications maintaining ten plants in each replication. The unit plot size was $3.0 \mathrm{X} 0.8 \mathrm{~m}$. The seedlings were watered until they got established. Thirty seedlings per row were kept at an average interval of $10 \mathrm{~cm}$ for normal growth and development. Insecticide, Admire @ $0.5 \mathrm{ml} / 1$ was applied for controlling aphids at an interval of 10 days and tracer @ $0.4 \mathrm{ml} / \mathrm{l}$ was also applied. The recommended doses of manure and fertilizers such as 10 ton/ha cow dung, $45 \mathrm{~kg}$ urea, $95 \mathrm{~kg}$ TSP and 40 $\mathrm{Kg} \mathrm{MP} / \mathrm{ha}$ were applied during final land preparation in the experimental field (Hussain et al., 2006). Thirty-five observations on qualitative (23) and quantitative (12) characters were recorded as per Descriptors for Vigna mungo and Vigna radiata (Revised), IBPGR (1985) and AVRDC-GRSU Characterization Record Sheet for mungbean (Table 1 and Table 2). Range, mean, genotypic and phenotypic coefficient of variation of quantitative characters were calculated (Burton, 1951). Phenotypic diversity for qualitative descriptors was determined by using Shannon-Weaver Diversity Index ( $\left.\mathrm{H}^{\prime}\right)$. $\mathrm{H}^{\prime}$ ranges from 0 to 1, where 1 indicates the minimum diversity (Yu Li et al., 1996). $\mathrm{H}^{\prime}$ was classified as low $\left(\mathrm{H}^{\prime}<0.50\right)$, intermediate $\left(\mathrm{H}^{\prime}=0.50-0.75\right)$ and high $\left(H^{\prime} \geq 0.75\right)$ based on Jamago (2000). Chi-square $\left(\chi^{2}\right)$ test was performed to compare the observed and the expected frequencies for each character. To calculate the expected frequencies for a uniform distribution, sum of the observed frequencies was divided by the number of classes. Principal Component Analysis, Principal Coordinate Analysis, Canonical Vector analysis and Cluster analysis were performed with Genstat 5 software.

\section{Results and Dicussion}

\section{(i) Characterization and phenotypic diversity index of qualitative character}

Variations of vegetative characters in blackgram are shown in Table 1. Green (1.64\%) and purple (98.36\%) epicotyl colours were found among the 61 accessions. Observed frequencies of epicotyl colour showed highly significant difference from the frequency expected in an equally distributed population. The maximum percentage of accessions exhibited purple colour (77 to 79\%) and the minimum accessions showed green or greenish purple colour (21 to 23\%) of petiole and stem. The colours of the blackgram leaf among the accessions were classified as light green $(21.31 \%)$, intermediate green $(67.21 \%)$ and dark green $(11.48 \%)$. Ovate $(81.97 \%)$, ovate-lanceolate $(11.48 \%)$ and rhombic $(6.56 \%)$ terminal leaflet shapes were observed among the accessions. Three types of growth habit viz. erect (81.97\%), semi-erect (13.11\%) and spreading (4.92\%) were exhibited among the 61 accessions. Indeterminate $((90.16 \%)$ and determinate $(9.84 \%)$ growth pattern were noted. The distribution of accessions in all descriptors was significantly different from the expected number of equal distribution (Table 1). Three types of raceme position, intermediate $(60.66 \%)$, no 
pods visible above canopy (22.95\%) and mostly above canopy (16.39\%) were observed. Two distinct immature pod colours with distinct frequencies like light green $(67.21 \%)$ and dark green $(32.79 \%)$ were observed however black $(65.57 \%)$ and brown (34.43\%) mature pods were found among the accessions. Sub-erect (81.97\%) and erect (18.03\%) pod attachment where as moderately (65.57\%), densely (21.31\%), sparsely (9.84\%) and glabrous pubescent $(3.28 \%)$ of pod pubescence were observed. The accessions exhibited hook $(86.89 \%)$ and knob $(13.11 \%)$ types of pod beak shape. Black $(75.41 \%)$, brown $(21.31 \%)$, grayedorange $(1.64 \%)$ and yellow-green $(1.64 \%)$ seed colour were exhibited at maturity stage after sun drying. More or less similar findings for growth habit and pattern, pod pubescence, mature pod and seed colour were reported by Gupta et al. (2001) and Panigrahi et al. (2014). The distribution of accessions in all descriptors was statistically different from the expected number of equal distribution (Table 1). All the accessions exhibited purple hypocotyl, none twining tendency, glabrous leaf pubescence, abundant leafiness, very light green calyx, yellow corolla (flower), drum-shaped seed, absent seed luster and nonconcave seed hilum.

Shannon Weaver Diversity Indices (SWDI), H' was estimated to assess the diversity in the vegetative and reproductive characters of the accessions. High phenotypic diversity was exhibited in colour of leaf, petiole, stem, immature and mature pods, and raceme position $\left(H^{\prime} \geq 0.75\right)$. Intermediate phenotypic diversity was exhibited in plant growth habit, terminal leaflet shape, pod attachment to peduncle, pod pubescence and pod beak shape $\left(H^{\prime}=0.50-0.75\right)$. Low phenotypic diversity was found in epicotyl colour, growth pattern and seed colour (H'<0.50, Jamago, 2000).

Table 1. Variation of different qualitative characters in blackgram

\begin{tabular}{l|l|c|c|c|c|c}
\hline Name of descriptor & \multicolumn{1}{c|}{$\begin{array}{c}\text { Descriptor } \\
\text { state }\end{array}$} & $\begin{array}{c}\text { No of } \\
\text { accession }\end{array}$ & $\begin{array}{c}\text { No of } \\
\text { accession }(\%)\end{array}$ & $\begin{array}{c}\chi 2 \\
\text { value }\end{array}$ & $\begin{array}{c}\text { Level } \\
\text { of sig. }\end{array}$ & SWDI \\
\hline Epicotyl colour & Purple & 60 & 98.36 & 57.07 & $* *$ & $0.12(\mathrm{~L})$ \\
& Green & 1 & 1.64 & & & \\
\hline Growth habit & Erect & 50 & 81.97 & 65.54 & $* *$ & $0.53(\mathrm{M})$ \\
& Semi-erect & 8 & 13.11 & & & \\
& Spreading & 3 & 4.92 & & & \\
\hline Growth pattern & Indeterminate & 55 & 90.16 & 39.36 & $* *$ & $0.46(\mathrm{~L})$ \\
& Determinate & 6 & 9.84 & & & \\
\hline Terminal leaflet & Ovate & 50 & 81.97 & 65.15 & $* *$ & \multirow{2}{*}{$0.54(\mathrm{M})$} \\
shape & Ovate-lanceo. & 7 & 11.48 & & & \\
& Rhombic & 4 & 6.56 & & & \\
\hline Leaf colour & Int green & 41 & 67.21 & 32.39 & $* *$ & $0.77(\mathrm{H})$ \\
& Light green & 13 & 21.31 & & & \\
& Dark green & 7 & 11.48 & & & \\
\hline
\end{tabular}


Table 1. Cont'd

\begin{tabular}{|c|c|c|c|c|c|c|}
\hline Name of descriptor & $\begin{array}{c}\text { Descriptor } \\
\text { state }\end{array}$ & $\begin{array}{c}\text { No of } \\
\text { accession }\end{array}$ & $\begin{array}{c}\text { No of } \\
\text { accession }(\%)\end{array}$ & \begin{tabular}{|c|}
2 \\
value
\end{tabular} & $\begin{array}{l}\text { Level } \\
\text { of sig. }\end{array}$ & SWDI \\
\hline \multirow[t]{2}{*}{ Petiole colour } & Greenish- purple & 13 & 21.31 & 20.08 & $* *$ & $0.75(\mathrm{H})$ \\
\hline & Purple & 48 & 78.69 & & & \\
\hline \multirow[t]{2}{*}{ Stem colour } & Purple & 47 & 77.05 & 17.85 & $* *$ & $0.78(\mathrm{H})$ \\
\hline & Green & 14 & 22.95 & & & \\
\hline \multirow[t]{3}{*}{ Raceme position } & Intermediate & 37 & 60.66 & 20.89 & $* *$ & $0.85(\mathrm{H})$ \\
\hline & No pods VAC & 14 & 22.95 & & & \\
\hline & $\begin{array}{l}\text { Mostly above } \\
\text { canopy }\end{array}$ & 10 & 16.39 & & & \\
\hline \multirow[t]{2}{*}{ Pod attachment } & Sub-erect & 50 & 81.97 & 24.93 & $* *$ & $0.68(\mathrm{M})$ \\
\hline & Erect & 11 & 18.03 & & & \\
\hline \multirow[t]{2}{*}{$\begin{array}{l}\text { Immature pod } \\
\text { colour }\end{array}$} & Light green & 41 & 67.21 & 7.23 & $* *$ & $0.91(\mathrm{H})$ \\
\hline & Dark green & 20 & 32.79 & & & \\
\hline \multirow[t]{4}{*}{ Pod pubescence } & $\begin{array}{l}\text { Moderately } \\
\text { pubescent }\end{array}$ & 40 & 65.57 & 57.62 & $* *$ & $\begin{array}{l}0.68 \\
(\mathrm{M})\end{array}$ \\
\hline & $\begin{array}{l}\text { Densely } \\
\text { pubescent }\end{array}$ & 13 & 21.31 & & & \\
\hline & $\begin{array}{l}\text { Sparsely } \\
\text { pubescent }\end{array}$ & 6 & 9.84 & & & \\
\hline & Glabrous & 2 & 3.28 & & & \\
\hline \multirow[t]{2}{*}{ Mature pod colour } & Black & 40 & 65.57 & 5.92 & $*$ & $0.93(\mathrm{H})$ \\
\hline & Brown & 21 & 34.43 & & & \\
\hline \multirow[t]{2}{*}{ Pod beak shape } & Hook & 53 & 86.89 & 33.20 & $* *$ & $0.56(\mathrm{M})$ \\
\hline & Knob & 8 & 13.11 & & & \\
\hline \multirow[t]{4}{*}{ Seed colour } & Black & 46 & 75.41 & 88.97 & $* *$ & $0.49(\mathrm{~L})$ \\
\hline & Brown & 13 & 21.31 & & & \\
\hline & Grayed-orange & 1 & 1.64 & & & \\
\hline & Yellow-green & 1 & 1.64 & & & \\
\hline
\end{tabular}

Where, SWDI-Shannon Weaver Diversity Indices; L-Low $(<0.50)$, M-Moderate $(0.50$ $0.75)$ and H-High- $(\geq 0.75)$, VAC- Visible Above Canopy

(ii) Descriptive statistics of quantitative characters

The extent of variability in respect to 12 descriptors in different accessions, measured in terms of range, mean, standard deviation, genotypic and phenotypic co-efficient of variations of blackgram accessions are shown in Table 2. Analysis of variance indicated that the accessions differed significantly for all characters studied except days to 1st seed emergence. All the accessions germinated in 3 to 4 days and seedling emergence was 50 to $93 \%$ in the field. Days to early flower was observed in BD-6867 and BD-6868 
(both 35 days) and late flower in MK-61 (50 days). The highest plant height was found in BD-10034 $(82.67 \mathrm{~cm})$ and the lowest in BD-6414 $(22.27 \mathrm{~cm})$. However, the longest branch was exhibited in BD-10033 $(71.73 \mathrm{~cm})$ followed by BD-10034 $(69.87 \mathrm{~cm})$ and lowest in BD-6414 $(16.52 \mathrm{~cm})$. The accessions produced number of primary branches, 2.67 (BD-6814) to 7.8 (MK-83) followed by 6.0 (MK-61). The highest terminal leaflet length was exhibited in BD-6873 $(11.18 \mathrm{~cm}$, BARI Mash-3) followed by BD-6866 $(11.08 \mathrm{~cm})$ while the lowest $6.20 \mathrm{~cm}$ was observed in BD-10042. This indicated that leaflet length of BD-6873 was almost two times larger than BD-10042. On the other hand, terminal leaflet width ranged from 6.43 (BD-10035) to $3.39 \mathrm{~cm}$ (BD6866) with an average of $4.45 \mathrm{~cm}$. The pod length ranged from 3.42 to $4.48 \mathrm{~cm}$ in BD-10043 and BD-6872 (BARI Mash-2), respectively. The accessions produced on average $4.01 \mathrm{~cm}$ long pod. The accessions exhibited $2.13 \mathrm{~g}$ (BD10046) to $4.49 \mathrm{~g}$ (BD-6871, BARI Mash-1) of 100-seed weights. The accessions produced 5 to 144 pods per plant from BD-10043 and BD-6873, respectively. On an average 37 pods per plant and 6.14 seeds per pods were found from the accessions. The variation in number of pods per plant might be due to differences in number of inflorescence per plant, flower dropping tendency and also due to the inherent potential of accessions. The maximum pod producing accessions were BD-6866 (107 pods), BD-6853 (94), BD-6857 (92), BD-6863 (80) and BD-6865 (77). The accessions produced 6 to 7 seeds per pod and seems to be superior than other accessions. Similar findings for plant height, primary branches, days to flowering, number of seeds per pod and 100-seed weight were found by Gupta et al.(2001) and Panigrahi et al. (2014). The highest GCV and PCV was found in number of pods per plant (26.2 and $28.4 \%$ ) followed by branch length (31.4 and 32.7\%) and number of primary branches $(20.31$ and $25.63 \%$ ) while the lowest in number of seeds per pod (3.33 and 7.60\%). All the characters exhibited higher estimates of PCV than corresponding GCV. A similar situation was also noticed for genotypic and phenotypic variance. The estimate of higher PCV than corresponding GCV might be due to higher degree of genotype $X$ environment interaction. In the present study, little difference between GCV and PCV $(<5 \%)$ were observed for the 10 characters studied indicating that the variability for these characters were primarily due to genotypic differences and selection for these characters were expected to be more effective. For the remaining character (i.e. number of primary branches and terminal leaflet width), big difference was observed between GCV and PCV (>5.0 \%), environmental influences was pronounced and selection should be performed carefully considering environmental factors. The results are in agreement with the findings of Priyanka et al. (2016) and Mishra (1983). The quantitative performance for individual accessions is presented in Table 2. 


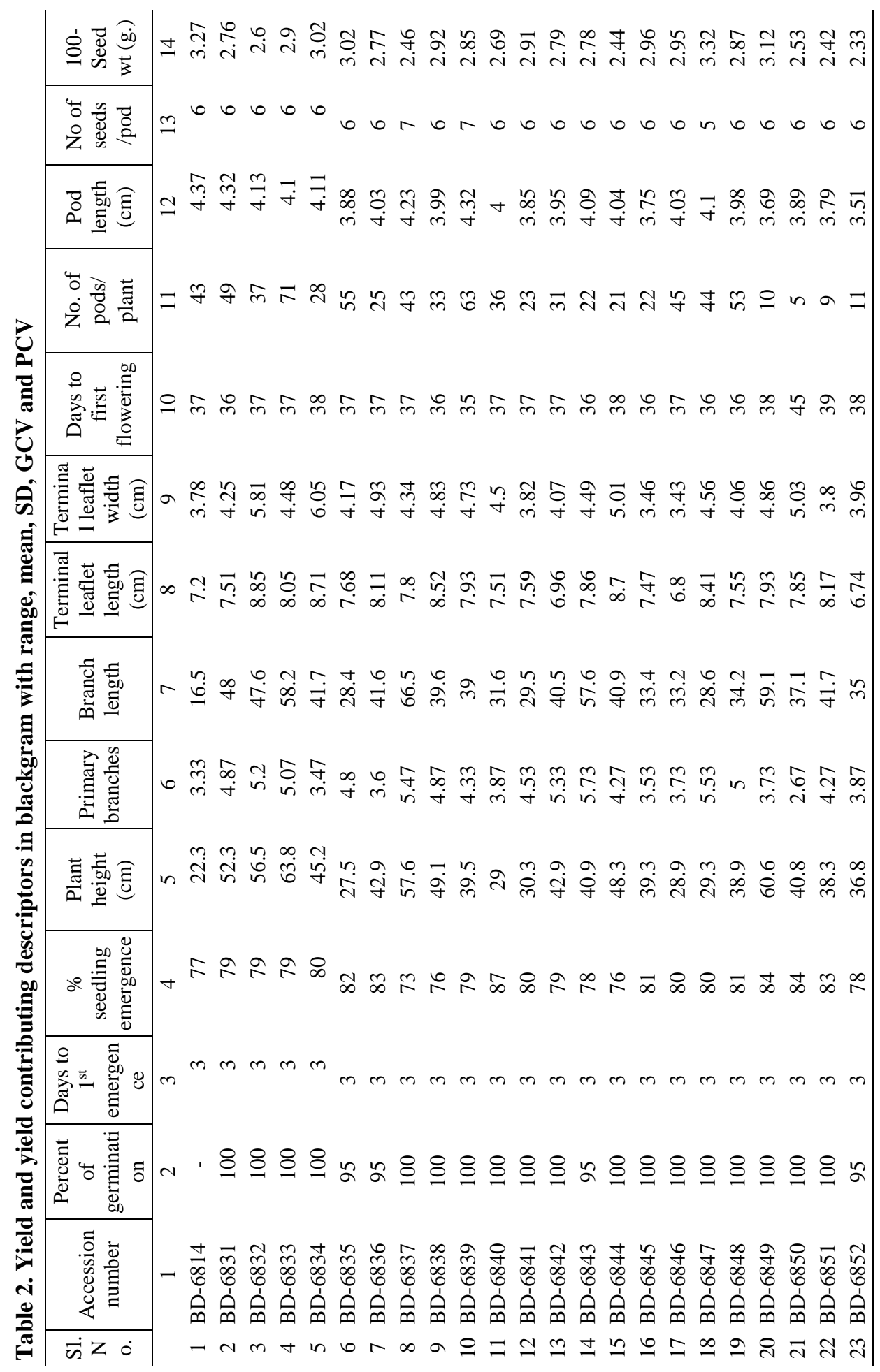




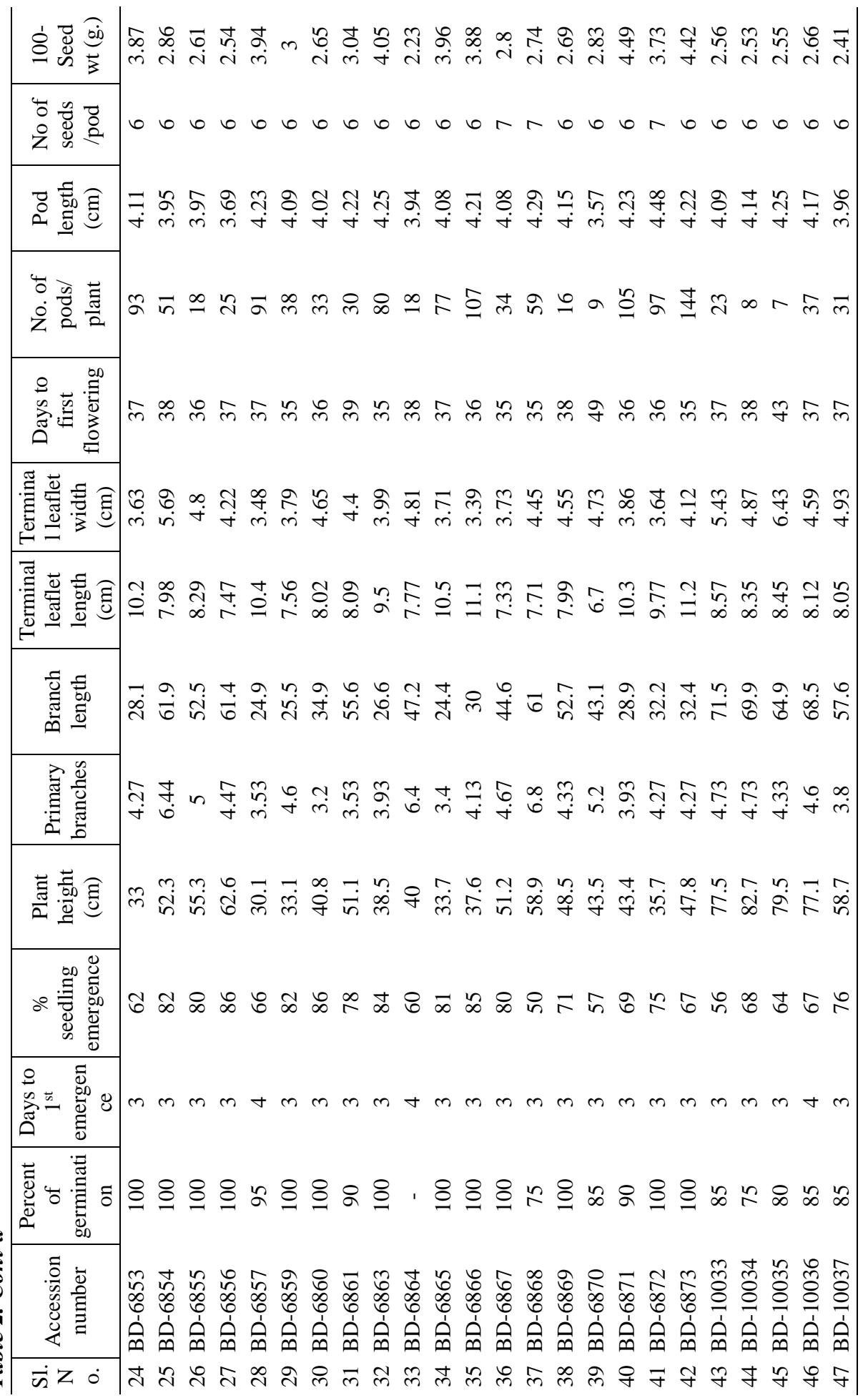




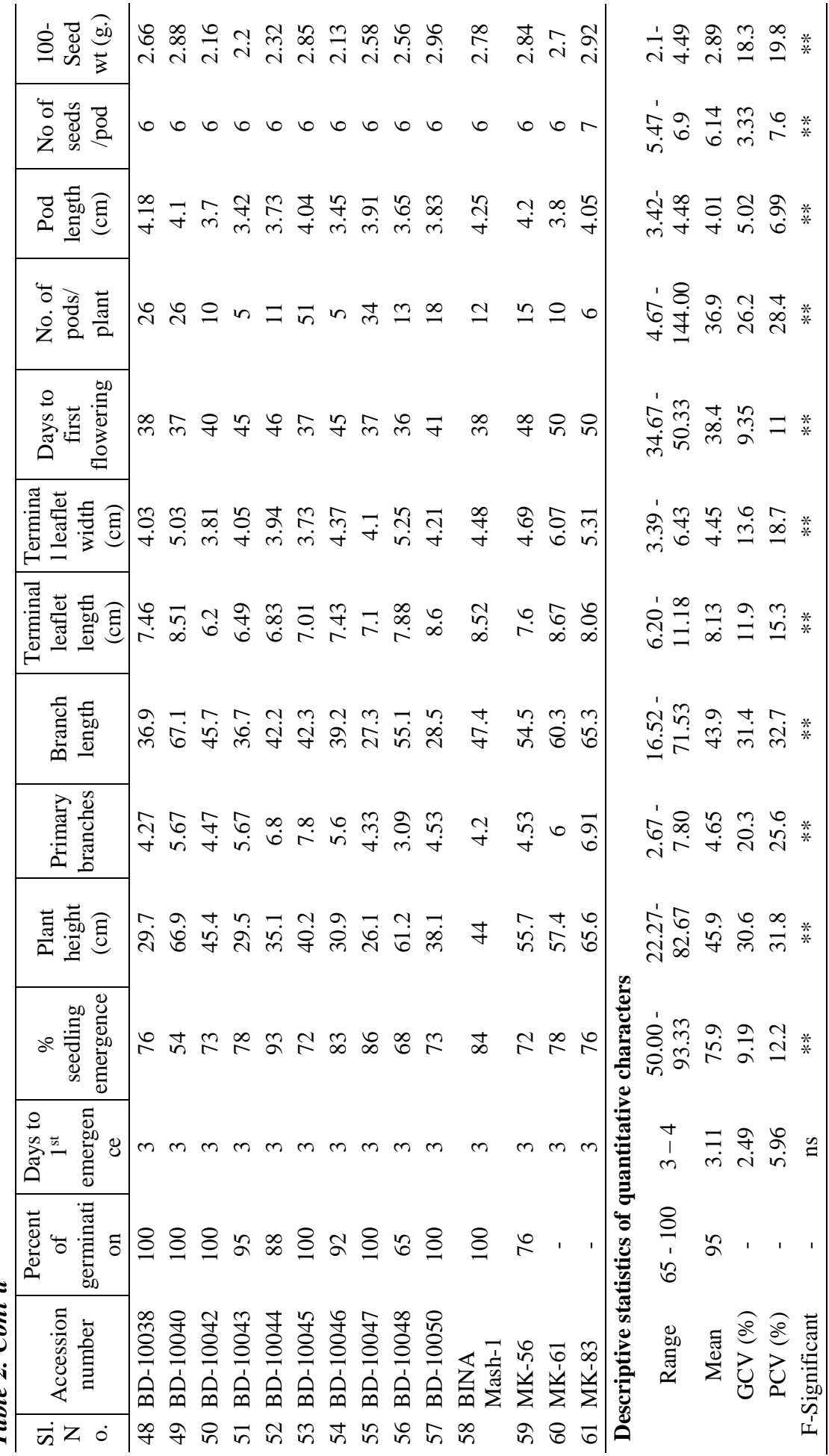




\section{( iii) Genetic diversity in blackgram}

The 61 accessions were fallen into 5 clusters on the basis of genetic diversity and the 22 accessions collected from 9 districts were fallen into 4 clusters. (Table 3 ). It means that the genetic constitution of the accessions was more important than their origin and distribution (Priyanka et al., 2016). Genetic divergence analysis was widely used to determine the genetic relationship among the genotypes and find out the suitable genotypes for future breeding programme. Genetic diversity analysis also helps in tagging and elimination of the duplicate accessions from genetic stock. Number of accessions in each cluster ranged from 8 (Clusters-IV) to 21 (Cluster-II).Cluster I contained 10 accessions includes Rangpur ( 1 acc.), Tangail (2), India (1, MAK-2) and unknown source (6). Cluster II was the largest cluster, composed of the 21 accessions from Jamalpur (1), Sherpur (1), Cumilla (1), Tangail (1), Mymensingh (1), Chapai Nawabganj (3), Moulvibazar (1), BINA Mash-1 and Unknown (11). Cluster III formed with the 11 accessions of Chapai Nawabganj (2) and unknown (9). Cluster IV composed of the 8 accessions, BARI Mash-1, BARI Mash-2, BARI Mash-3, MAK-1, Pant (India) and Unknown (3). Cluster V consisted of 11 accessions from Tangail (3), Jessore (1), Chapai Nawabganj (4) and unknown (3). Six accessions from Tangail were distributed into Cluster-I, Cluster-II and Cluster-V and nine accessions from Chapai Nawabganj were distributed into Cluster-II, Cluster-III and Cluster-V. Accessions were collected from the same geographic origin (districts) were distributed into different clusters. In many cases, the accessions from different districts were grouped in the same cluster indicating their close affinity. This result suggested that the accessions within a cluster might have some degree of ancestral relationship.

The intra-cluster distance ranged from 0.30 (Cluster-IV) to 1.17 (Cluster-V) (Table 4). This showed cluster $\mathrm{V}$ was more heterogeneous than any other clusters. Maximum inter cluster distance was estimated between clusters IV and V (11.38) followed by clusters II and IV (9.78), suggesting wide diversity between the accessions of these groups. On the contrary, the minimum intercluster distance was observed between clusters I and II (3.37) indicated close relationship (Table 5). Panigrahi et al. (2014) found, 21.57 of maximum inter cluster distance between clusters IV and VI. The divergence within the cluster indicates the divergence among the genotypes in the same cluster. Critical assessment of clusters showed that clusters were heterogeneous within them and between each other based on major character relation. The lower $\mathrm{D}$ value between their characters suggested that the genetic constituents of these accessions in one cluster were in close proximity with those accessions in other cluster. Similar result was reported earlier by Priyanka et al. (2016).

The cluster means of different characters are presented in Table 5. The cluster means of the quantitative traits help to identify the diverse genotypes for genetic manipulation. Accessions belong to Cluster I showed the highest primary branches and number of seeds per pod. Accessions of Cluster II produced the lowest pod length, number of seeds per pod and 100-seed weight. Cluster III had 
the lowest cluster mean values for plant height, terminal leaflet length, early flowering and number of seeds per pod. The highest terminal leaflet length, number of pods per plant, pod length and 100-seed weight were obtained from cluster-IV. The maximum inter cluster distance was observed between cluster IV and V (11.38) followed by cluster II and IV (9.78) and cluster I and IV (9.38), suggesting that the accessions belonging to these clusters may further be used as parents for hybridization programme to develop desirable hybrids because crosses between genetically divergent parents will generate transgressive segregants (Mehandi et al., 2015). Cluster IV showed the lowest number of primary branches, branch length, terminal leaflet width and days to early flowering. Cluster V exhibited the highest plant height, branch length, leaflet width, days to late flowering. In principal component analysis PC1, PC2 and PC3 were observed to contribute $74 \%, 24 \%, 1 \%$, respectively of the total divergence. On the basis of cluster analysis the accessions BD-6853, BD-6857, BD-6863, BD-6865 and BD-6866 belonging to cluster IV showed better performance for terminal leaflet length, number of pods per plant, pod length and hundred seed weight. Genotypes belonging to different clusters having high means for desired characters and with maximum divergence may successfully be used in hybridization programmes.

Table 3. Distribution of accessions in five clusters of blackgram

\begin{tabular}{c|c|l}
\hline Cluster & $\begin{array}{c}\text { No. of } \\
\text { accession }\end{array}$ & \multicolumn{1}{|c}{ Accessions with their place of collection } \\
\hline Cluster-I & 10 & $\begin{array}{l}\text { BD-6831, BD-6832, BD-6833, BD-6837, BD-6854 \& } \\
\text { BD-6861 Unknown; MAK-2-India; BD-6868-Rangpur; } \\
\text { BD-10036 \& BD-10037-Tangail }\end{array}$ \\
\hline Cluster-II & 21 & $\begin{array}{l}\text { BD-6834, BD-6836, BD-6838, BD-6841, BD-6842, BD- } \\
\text { 6843, BD-6844, BD-6845, BD-6850, BD-6851 \& BD- } \\
\text { 6852-Unknown; BD-6854-Jamalpur; BD-6869-Sherpur; } \\
\text { BD-6870-Cumilla; BD-10038-Tangail,; BD-10042- } \\
\text { Mymensingh; BD-10043, BD-10044 \& BD-10046 - } \\
\text { Chapai Nawabganj; BD-10050-Moulvibazar; BINA } \\
\text { Mash-1 }\end{array}$ \\
\hline Cluster-III & 11 & $\begin{array}{l}\text { BD-6814, BD-6835, BD-6839, BD-6840, BD-6846, BD- } \\
\text { 6847, BD-6848, BD-6859 \& BD-6860-Unknown; BD- } \\
\text { 10045 \& BD-10047-Chapai Nawabganj }\end{array}$ \\
\hline Cluster-IV & 8 & $\begin{array}{l}\text { BD-6853, BD-6857 \& BD-6863-Unknown; BD-6865 } \\
\text { (MAK-1); BD-6866 (PANT); BD-6871-BARI Mash-1, } \\
\text { BD-6872-BARI Mash-2, BD-6873-BARI Mash-3 }\end{array}$ \\
\hline Cluster-V & 11 & $\begin{array}{l}\text { BD-6849, BD-6855 \& BD-6856-Unknown; BD-10033, } \\
\text { BD-10034 \& BD-10035-Tangail; BD-10040-Jessore, BD- } \\
\text { 10048, MK-56, MK-61 \&MK-83-Chapai Nawabganj }\end{array}$ \\
\hline Total & $\mathbf{6 1}$ & \\
\hline
\end{tabular}


Table 4. Intra-and Inter cluster distance of different accessions in blackgram

\begin{tabular}{l|c|c|c|c|c}
\hline Name of character & Cluster-I & Cluster-II & Cluster-III & Cluster-IV & Cluster-V \\
\hline Cluster-I & $\mathbf{0 . 6 7}$ & & & & \\
Cluster-II & 3.37 & $\mathbf{0 . 8 1}$ & & & \\
Cluster-III & 4.49 & 3.53 & $\mathbf{0 . 6 2}$ & & \\
Cluster-IV & 9.38 & 9.78 & 8.55 & $\mathbf{0 . 3 0}$ & \\
Cluster-V & 3.72 & 4.32 & 7.13 & 11.38 & $\mathbf{1 . 1 7}$ \\
\hline
\end{tabular}

Where, Diagonal and bold indicate intra cluster distance

Table 5. Cluster mean of different characters in blackgram

\begin{tabular}{l|c|c|c|c|c}
\hline Name of character & Cluster-I & Cluster-II & Cluster-III & Cluster-IV & Cluster-V \\
\hline Plant height $(\mathrm{cm})$ & 57.96 & 39.98 & $32.32^{*}$ & 37.49 & $65.91^{* *}$ \\
\hline Primary branches & $5.04 * *$ & 4.65 & 4.59 & $3.97^{*}$ & 4.84 \\
\hline Branch length & 56.96 & 40.87 & 31.05 & $28.45^{*}$ & $61.95^{* *}$ \\
\hline Terminal leaflet length $(\mathrm{cm})$ & 7.95 & 7.65 & $7.52^{*}$ & $10.36^{* *}$ & 8.16 \\
\hline Terminal leaflet width $(\mathrm{cm})$ & 4.67 & 4.4 & 4.14 & $3.73^{*}$ & $5.18^{* *}$ \\
\hline Days to first flowering & 37 & 40 & $36^{*}$ & $36^{*}$ & $41^{* *}$ \\
\hline Pods/plant & 44 & 17 & 45 & $99 * *$ & $15^{*}$ \\
\hline Pod length (cm) & 4.15 & $3.87 *$ & 4.07 & $4.23^{* *}$ & 3.97 \\
\hline No. of seeds /pod & $6.30^{* *}$ & $6.00^{*}$ & $6.00^{*}$ & 6.12 & 6.09 \\
\hline 100-seed wt. (g) & 2.72 & $2.61 *$ & 2.91 & $4.04 * *$ & 2.71 \\
\hline
\end{tabular}

Within rows, * and ** indicate minimum and maximum cluster mean values, respectively.

\section{Conclusion}

Low to high phenotypic diversity index of qualitative characters were exists among the blackgram accessions. Highly significant variations were found among the quantitative characters. The accessions were grouped into five clusters. The accessions BD-6853, BD-6857, BD-6863, BD-6865 and BD-6866 may be selected for varietal improvement programme.

\section{References}

Anwar, M. N., M. S. Huq, S. K. Nandi and M. S. Islam. 2000. Growth, yield component and curd yield of broccoli as influenced by N, P, K, S, and Mo in grey terrrace soil. Bangladesh J. Agril. Res. 25 (4): 685-691.

BBS. 2018. Bangladesh Bureau of Statistics, Year Book of Agricultural Statistics-2017, Ministry of Planning, Government of the People's Republic of Bangladesh, Dhaka. p.112-113. 
Burton, G. W.1951.Quantitative inheritance in pearl millet (Pennisetum glaucum). Agron. J. 43: 409-417.

FAO. 2014. Genebank Standards for Plant Genetic Resources for Food and Agriculture. Rev. ed. Rome. Itali

Frankel, O. H. 1986. Genetic resources- museum or utility. In: Proc. of Plant Breeding Symposium, DSIR. 1986. Department of Scientific and Industrial Research, Wellington.

Gupta, S. R., R. A. Singh, S. Gupta and H. K. Dikshit. 2001. Variability and its characterization in Indian collections of blackgram [Vign amungo (L.) Hepper].Plant Genetic Resources Newsletter.127 : 20-24.

Hussain M. S., M. M. Rahman, M. H. Rashid, A. T. M. Farid, M. A. Quyum, M. Ahmed, M. S. Alam and K. M. S. Uddin. 2006. Handbook on Agro-technology. $4^{\text {th }}$ edition. BARI, Gazipur 1701. Bangladesh.

IBPGR. 1985. IBPGR advisory committee on seed storage report of the third meeting, IBPGR, Rome, Italy.

Jamago, J. M. 2000. Morpho-agronomic and molecular diversity of the Philippine mungbean (Vigna radiata L.) germplasm.University of the Philippines Los Banos.The Philippines. p174

Jeevitha S., R. Karthikeyan, M. Vignesh, A. Malarkodi, R. Tirumalai, A. J. Nainu, R. Anandan, M. Prakash and S. Murugan. 2018. Estimation of morphological and molecular genetic diversity in blackgram [Vigna mungo (L.) Hepper] under YMV hotspot regime. Horticultural Biotechnology Research. 4: 06-09

Mehandi, S., I.P. Singh, A. Bohra and C.M. Singh.(2015). Multivariate analysis in green gram [Vigna radiata (L.)Wilczek].Legume Research. 38 : 758-762.

Mishra, R. C.1983. Variability, correlation and path coefficient analysis in blackgram. Andhra Agric. J., 30: 239-43.

Patidar M., H. Sharma and S. Haritwal. 2018. Genetic variability studies in Blackgram (Vigna mungo (L.) Hepper).Int. J. Chemical Studies. 6(2): 1501-1503

Panigrahi, K. K., A. Mohanty and B. Baisakh. 2014. Genetic divergence, variability and character association in landraces of blackgram (VignaMungo[L.] Hepper) from Odisha. J. Crop and Weed.10 (2): 155-165.

Priyanka G., M. Suhel, G. Rahulkumar and G. M. Lal. 2016. Genetic diversity study in blackgram (Vigna mungo L.Hepper) genotypes. Int. J. Agric. Sci. 8 (49): 2056-2058.

Sinha Y., G. M. Lal, P.K. Rai and B. M. Bara. 2018. Studies on genetic diversity for yield and its components in blackgram (VignamungoL. Hepper) genotypes. Global Journal of Bioscience and Biotechnology. 7 (3): 370-374.

Yashoda, T., H. Gowda , V. Ellur and Swetha. 2016. Genetic variability and character association for Yield and its components in blackgram [Vignamungo (L.) Hepper]. The bioscan. 11(2):1059-1063, (Supplement on Genetics and Plant Breeding).

Yu Li W., K. Shuzhi, C.A.O. Youngsheng and X. Zhang. 1996. A phenotypic diversity analysis of foxtail millet (Setaria italica L.P. Beauv) landrace of Chinese origin. Genetic Resour.Crop Evol.,43: 377-384. 
